\title{
Beware of Phenytoin Self-Harm In Children
}

Sir,

Antiepileptic drug (AED) poisoning usually occurs in the individuals who are on AEDs either as an attempt to suicide or self-harm. There are several reports of phenytoin toxicity because of its narrow therapeutic window. Phenytoin toxicity in children usually occurs as an overdose of treatment of epilepsy or following high dose of intravenous (IV) therapy for status epilepticus. ${ }^{[1-3]}$ There is, however, no report on phenytoin poisoning as an attempt of suicide or self-harm. In this communication, we report a child with phenytoin poisoning as a result of self-harm.
A 2-year-old boy got angry while playing and locked himself in a room. His parents requested him to open the door. They saw him opening the bottle and consuming all the tablets of phenytoin which was kept for his elder sister who is suffering from focal epilepsy. Parents have broken the door and took out some of the leftover tablets from his mouth and rushed to nearby hospital. His blood analysis and electrolytes were normal. $\mathrm{He}$ was treated with IV fluid and Ryle's tube feeding for 7 days in the local hospital. He was referred to us because of persistent altered sensorium and abnormal movements of all the four limbs. On examination, he 
had fever $\left(102^{\circ} \mathrm{F}\right)$ and his blood pressure was $100 / 70$ $\mathrm{mmHg}$ and pulse 140/m regular. His Glasgow Coma Scale score was 9. Pupils were reactive. He had choreiform movements of all four limbs including tongue [Video 1a]. Tendon reflexes were diminished, but planter responses were extensor. His complete blood counts, kidney, liver and thyroid function tests, and serum electrolytes were normal. His electrocardiogram was normal and electroencephalography revealed diffuse delta slowing. He was treated with IV normal saline, ceftriaxone $250 \mathrm{mg} 12$ hourly, and folic acid $5 \mathrm{mg}$ daily. His consciousness and chorea started improving by the $4^{\text {th }}$ day. On the $6^{\text {th }}$ day, he started walking with support when he was found to have ataxia [Video 1b]. He was discharged on $15^{\text {th }}$ day when he was conscious, chorea disappeared but had ataxia. At 1-month follow-up, the child was normal.

\section{Declaration of patient consent}

The authors certify that they have obtained all appropriate patient consent forms. In the form the patient(s) has/have given his/her/their consent for his/ her/their images and other clinical information to be reported in the journal. The patients understand that their names and initials will not be published and due efforts will be made to conceal their identity, but anonymity cannot be guaranteed.

\section{Acknowledgment}

We would like to thank Mr. Shakti Kumar for secretarial help.

\section{Financial support and sponsorship}

Nil.

\section{Conflicts of interest}

There are no conflicts of interest.
Varun Kumar Singh, Jayantee Kalita, Usha Kant Misra

Department of Neurology, Sanjay Gandhi Postgraduate Institute of Medical Sciences, Lucknow, Uttar Pradesh, India

Address for correspondence: Dr. Jayantee Kalita, Department of Neurology, Sanjay Gandhi Postgraduate Institute of Medical Sciences, Raebareily Road, Lucknow - 226 014,

Uttar Pradesh, India. E-mail: jayanteek@yahoo.com

\section{REFERENCES}

1. Sharma B, Handa R, Prakash S, Nagpala K, Gupta P. Phenytoin toxicity presenting as encephalopathy with fatal outcome: A case report. J Neurol Res 2013;3:184-6.

2. Rosenblum E, Rodichok L, Hanson PA. Movement disorder as a manifestation of diphenylhydantoin toxicity. Pediatrics 1974;54:364-6.

3. Misra UK, Kalita J. Clinical Electroencephalography. India, New Delhi: Elsevier; 2005. p. 336.

This is an open access journal, and articles are distributed under the terms of the Creative Commons Attribution-NonCommercial-ShareAlike 4.0 License, which allows others to remix, tweak, and build upon the work non-commercially, as long as appropriate credit is given and the new creations are licensed under the identical terms.

\section{Video available on: www.ruralneuropractice.com}

\begin{tabular}{|l|l|}
\hline \multicolumn{2}{|c|}{ Access this article online } \\
\hline Quick Response Code: & Website: \\
\hline & \\
\cline { 2 - 2 } & \\
\hline
\end{tabular}

How to cite this article: Singh VK, Kalita J, Misra UK. Beware of phenytoin self-harm in children. J Neurosci Rural Pract 2018;9:283-4.

(c) 2018 Journal of Neurosciences in Rural Practice | Published by Wolters Kluwer - Medknow 